\title{
Viewpoint
}

\section{Synovial lining cell hyperplasia in rheumatoid arthritis: dogma and fact}

\author{
B HENDERSON, ' P A REVELL, ${ }^{2}$ AND J C W EDWARDS 3
}

From the ${ }^{1}$ Department of Pharmacology, Wellcome Research Laboratories, Langley Court, Beckenham, $\stackrel{0}{0}$

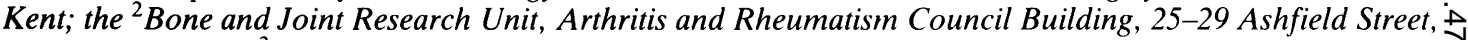
London; and the ${ }^{3}$ Department of Rheumatology Research, University College and Middlesex Hospital ${ }_{+}$ Medical School, Arthur Stanley House, Tottenham Street, London

The synovial lining of the diarthrodial joint is a tissue whose most striking microscopic feature is a layer of cells lying adjacent to the joint cavity. These are known as synovial lining cells or synoviocytes. ' In inflamed, and particularly in rheumatoid, joints the synovial lining cell layer is thickened with perhaps a three to five cell thick layer in contrast with the one to two cells of the normal joint. The simplest explanation for these extra cells is an increase in the rate of cell division, and it is generally assumed that the hyperplasia of the synovial lining cells is due to mitotic activity. This assumption has become a dogma of modern rheumatology, enshrined both in reviews and in textbooks. ${ }^{23}$ As is soon clear to anyone examining the histology of the rheumatoid synovial lining, however, mitotic figures are a rare sight.

Cell division can be assessed by a number of techniques, including tritiated thymidine autoradiography, Feulgen microspectrophotometry, and, more recently, by use of a monoclonal antibody which recognises a nuclear antigen found in dividing cells. The earliest studies of synovial lining cell division used tritiated thymidine incorporation into cultured synovial explants and failed to find increased incorporation in rheumatoid tissue. ${ }^{45} \mathrm{Up}$ to $4 \%$ of cells were labelled in rheumatoid arthritis. ${ }^{4}$ This finding of low proliferative activity was confirmed by use of Feulgen microspectrophotometry. ${ }^{67}$ Recent studies, using a monoclonal antibody which recognises dividing cells, ${ }^{89}$ show an even lower rate of division of these cells in the rheumatoid joint. The proportion of labelled cells was between 1:2000

Accepted for publication 26 October 1987

Correspondence to Dr B Henderson, Department Pharmacology, Wellcome Research Laboratories, Langley Court. Beckenham, Kent BR3 3BS. and 1:30000 even in rheumatoid arthritis. Further $\vec{\longrightarrow}$ more, when a double labelling, immunohistochemical method was used none of those sparse cells marked as proliferating showed the presence of $\infty$ lysozyme, which is a macrophage marker and shown ${ }^{\circ}$ to be present in type A synovial cells." 10 WeO therefore have the situation of increased numbers of cells but with no evidence of cell division. Synovialo lining cells can apparently be stimulated to divide, ֶ however. In rabbits with antigen induced arthritis, $a \stackrel{\mathbb{Q}}{\circledR}$ lesion resembling rheumatoid arthritis, there is a $\vec{\Rightarrow}$ rapid rise in the rate of cell division in this 3 population of cells, ${ }^{11-1.3}$ but within two to three months of inducing arthritis the rate of cell divisiono has declined to normal levels. Despite this, the synovial lining cell layer remains hyperplastic. This? hyperplasia depends upon the continuance of the synovitis. Thus in animals with a resolving synovitis? the increased numbers of synovial lining cells declineo in parallel with the decrease in inflammation. ${ }^{13}{ }^{14}$ The conclusion must be that the so-called hyperplasia of윽 the rheumatoid synovial lining cell layer is an active $>$ continuing process.

If the increased numbers of synovial lining cells in the rheumatoid joint are not due to an accelerationof the cell cycle what is causing this increase in cells 0 and does hyperplasia remain an appropriate term? $\mathbb{\omega}$ One important clue to this question has come fromo the use of the beige mouse, which carries ao homozygous gene $(\mathrm{bg})$ that codes for the expression of giant granules in a variety of cell types. The? granules have proved to be useful genetic markers 0 for tracing mononuclear phagocytes. Injection of ${ }_{\vec{P}}$ bone marrow cells from beige mice into irradiated $\stackrel{\mathbb{Q}}{\circ}$ histocompatible recipients led to the appearance of cells with giant granules in the synovial lining cello layer. Electron microscopic examination of these 
granule bearing cells showed them to have the characteristic ultrastructure of type A synovial lining cells. ${ }^{15}{ }^{16}$ Thus in the normal joint the type A cells appear to derive from bone marrow precursors. Further evidence for the recruitment of cells to the joint comes from experiments in guinea pigs using an antigen induced model of arthritis. ${ }^{17}$ The labelling index of the synovial lining cell layer was compared in animals receiving tritiated thymidine injected directly into the joint with that in animals where the tritiated thymidine was given systemically and localised at first to the bone marrow. The labelling index was $2.5 \%$ in the former case, $77 \%$ in the latter. Is this process accelerated in rheumatoid arthritis and does it account for the thickening of the synovial lining cell layer? As yet these questions cannot be answered. There is direct evidence, however, that cells derived from bone marrow may account for the increase in synovial lining cells. In non-rheumatoid synovial lining $20-30 \%$ of synovial lining cells are HLA-DR positive. ${ }^{18}$ These are the type A macrophage-like cells by immunoelectronmicroscopy. ${ }^{19} 20$ In contrast, in rheumatoid tissue $80-100 \%$ of the synovial lining cells are HLA-DR positive. ${ }^{18}$ This suggests that the bulk of the synovial lining cells in the rheumatoid joint are derived from bone marrow. Of course, class II major histocompatibility complex antigens are found on cells other than macrophages. By use of monoclonal antibodies which recognise a range of specific epitopes on mononuclear phagocytes, however, it has been shown that most synovial lining cells in the rheumatoid joint are indeed mononuclear phagocytes. ${ }^{21} 22$ Most cells bore markers for blood monocytes, suggesting that there was rapid incorporation of blood borne monocytes into the synovial lining cell layer. ${ }^{21} 22$

In conclusion, there is increasing evidence for the hypothesis that synovial lining cell hyperplasia in rheumatoid arthritis is due, not to increased cell division, but to an increased recruitment of mononuclear phagocytes derived from bone marrow. The signals which stimulate this recruitment of cells and their accretion into a lining layer are not known. The synovial lining layer plays a major part in the pathology of rheumatoid arthritis. ${ }^{123}$ Interference with this recruitment and/or maturation into a lining cell layer promises to be of value in the treatment of rheumatoid arthritis.

\section{References}

1 Henderson B, Pettipher E R. The synovial lining cell: biology and pathobiology. Semin Arthritis Rheum 1985; 15: 1-32.
2 Harris E D. A modern scheme for joint destruction in rheumatoid arthritis. Articular Synovium Int Symp. Bascl: Karger, 1982; 107-16.

3 Zvaifler $\mathrm{N}$ J. Overview of etiology and pathogenesis. In: Utsinger P D, Zvaifler N J, Ehrlich G E, eds. Rheumatoid arthritis: etiology, diagnosis and management. Philadelphia: Lippincott, 1985: 151-8.

4 Mohr W, Beneke G, Mohing W. Proliferation of synovial lining cells and fibroblasts. Ann Rheum Dis 1975; 34: 219-24.

5 Nykanen P. Helve T, Kankaanpaa U, Larsen A. Characterisation of the DNA-synthesizing cells in rheumatoid synovial tissue. Scand J Rheumatol 1978; 7: 118-22.

6 Coulton L A, Henderson B. Bitensky L. Chayen J. DNA synthesis in human rheumatoid and non-rheumatoid synovial lining. Ann Rheum Dis 1980; 39: 241-7.

7 Coulton L A. Henderson B. Chayen J. The assessment of DNA-synthetic activity. Histochemistry 1981; 72: 91-9.

8 Mapp P I, Lalor P A. Hall P A. Revell P A. Synovial intimal cells show only a low level of proliferative activity [Abstract]. Br J Rheumatol 1986; (suppl 2): 37.

9 Revell P A, Mapp P I, Lalor P A, Hall P A. Proliferative activity of cells in the synovium as demonstrated by a monoclonal antibody, Ki67. Rheumatol Int 1987; 7: 183-6.

10 Mapp P I, Revell P A. Ultrastructural localisation of muramidase in the human synovial membrane. Ann Rheum Dis 1987; 46: 30-7.

11 Henderson B, Glynn L E, Bitensky L, Chayen J. Evidence for cell division in synoviocytes in acutely inflamed rabbit joints. Ann Rheum Dis 1981: 40: 177-81.

12 Henderson B. Glynn L E, Chayen J. Cell division in the synovial lining in experimental allergic arthritis: proliferation of cells during the development of chronic arthritis. Ann Rheum Dis 1982; 41: 275-81.

13 Henderson B, Glynn L E, Chayen J. Experimental allergic arthritis in the rabbit: alterations in the cellularity and the rate of cellular proliferation in the synovial linings of the challenged joints of rabbits immunized with antigen in Freund's incomplete adjuvant. BrJ Exp Pathol 1982; 63: 5-12.

14 Dreher R. Experimentelle Immunarthritis. Munchen-Grafelfing: Work-Verlag, 1983.

15 Edwards J C W, Willoughby D A. Demonstration of bonc marrow-derived cells in synovial lining by means of giant intracellular granules as genetic markers. Ann Rheum Dis 1982; 41: $177-82$.

16 Edwards J C W. The origin of the type A synovial lining cell. Immunobiology 1982; 161: 227-31.

17 Dreher R. The origin of synovial type A cells during inflammation: an experimental approach. Immunobiology 1982; 161: 232-45.

18 Poulter L W, Duke O, Hobbs S. Histochemical discrimination of HLA-DR positive cells populations in the normal and arthritic synovial lining. Clin Exp Immunol 1983; 51: 117-25.

19 Mapp P I. Studies on the intimal cells of the synovial membrane. University of London, 1987. (PhD thesis.)

20 Mapp P I, Revell P A. The localisation of HLA-DR antigen to type A synoviocytes by immunoelectronmicroscopy [Abstract]. Br J Rheumatol 1986; 25 (suppl 1): 14.

$21 \mathrm{Hogg}$ N, Palmer D G, Revell P A. Mononuclear phagocytes of normal and rheumatoid synovial membrane identificd by monoclonal antibodies. Immunology 1985; 56: 673-81.

22 Palmer D G, Selvendran Y, Allen C, Revell P A, Hogg N. Features of synovial membrane identified with monoclonal antibodies. Clin Exp Immunol 1985; 59: 529-38.

23 Henderson $\mathrm{B}$. Edwards $\mathrm{J} \mathrm{CW}$. The synovial lining in health and disease. London: Chapman and Hall, 1987. 